\title{
JUURNAL.RU
}

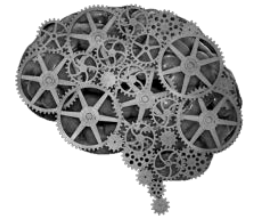

COMPANY GROUP "INTELLEKT"

\author{
Васильева Д. Е. \\ УрГУПС \\ Екатеринбург, Россия
}

doi: 10.18411/lj2016-5-1-01

\section{Развитие производительных сил как фактор общественного разделения труда}

На сегодняшний день существует множество определений производительных сил. Начиная от самых простых, понятных всем и заканчивая самыми сложными, глубоко научными определениями.

Обобщая их можно сказать, что:

Производительные силы - это система личных и вещественных факторов производства в их взаимодействии, функциональное значение которой преобразование вещества для удовлетворения потребностей человека [5]. Таким образом, производительные силы - это любое действие человека, с использованием любого предмета, с помощью которого он сможет достигнуть своей цели.

Производительные силы это процесс, включающий в себя: предмет труда (то, на что направлено воздействие человека), средство труда (инструменты, механизмы, машины) и производительная инфраструктура (здания, дороги, энергосети и др.).

Bсе производительные силы можно разделить на три формы: естественные, общественные и всеобщие.

Естественные производительные силы - это самый простой процесс, включающий в себя самого человека и окружающие его предметы. Они существовали задолго до нашей эры. Во времена первобытного строя. 
Общественные производительные силы начали свое развитие в традиционном обществе, когда человек научился сам создавать орудия труда и с их помощью влиять на окружающий его мир. Общественные производительные силы прогрессировали и развивались примерно до начала двадцатого века.

Всеобщие производительные силы это превосходство человека над природой. Своеобразное регулирование всех сфер общественного производства с помощью науки, изменение самого процесса осуществления деятельности на предприятиях. Когда наука начала свое стремительное развитие в середине двадцатого века, тогда и начали развиваться всеобщие производительные силы. Вся суть всеобщих производительных сил состоит в автоматизации производства, создании новых механизмов, упрощающих работу самого человека.

Стоит также отметить тот факт, что главным элементом производительных сил во все времена был именно человек [3]. Ведь производительные силы это система, развитие которой зависит только от неё самой. А человек является одним из главных факторов, влияющих на производительные силы.

Существует три типа производительных сил: доиндустриальные, индустриальные и постиндустриальные. Их можно прировнять к трем типам развития общества: традиционному, индустриальному и информационному.

Доиндустриальный тип производительных сил базируется на традиционном типе общества. В наши дни очень мало стран с таким типом производительных сил, так как научно - технический прогресс ушел далеко вперед от времен традиционного общества, где сельское хозяйство стояло на первом месте. Примерами таких стран могут стать Африка и Латинская Америка.

Индустриальный тип производительных сил является основным в наши дни. Он охватывает большинство стран. 
Что же касается постиндустриального типа, то тип, основанный на информационных технологиях, распространен лишь в некоторых районах таких стран как Япония, Великобритания и др.

В двадцатом веке, когда господствовали общественные производительные силы, Владимир Ильич Ленин высказал теорию о том, что главным условием, движущим развитие производительных сил, является революция, классовая борьба. «Только борьба воспитывает эксплуатируемый класс, только борьба открывает ему меру его сил, расширяет его кругозор, поднимает его способности, проясняет его ум, выковывает его волю»[2].

Разумеется, революция может дать огромный толчок к развитию производительных сил, но это не будет иметь никакого смысла, если человечество остановится в своем развитии. Именно поэтому главным фактором совершенствования производительных сил является научно - технический прогресс.

Научно - технический прогресс - это развитие науки и техники, которое ведет к открытию нового и улучшению старого. Научно - технический прогресс является главным фактором, влияющим на развитие общества. Это необратимый процесс, влекущий за собой коренные изменения в жизни человека. Он неизбежен. Мы стремимся улучшить свою жизнь и научно - технический прогресс помогает нам в этом. Изобретение машин, телефонов, компьютеров, рабочих станков и др. Все это значительно облегчило нашу жизнь. Именно поэтому научно - технический прогресс можно назвать основным фактором развития производительных сил. Автоматизация производства и постепенное снижение зависимости от природных источников сырья, все это послужило толчком к развитию производительных сил человечества. А это, в свою очередь, является главным фактором общественного разделения труда.

Труд - это какая-либо деятельность человека, требующая от него, как умственного, так и физического напряжения. Любая работа требует труда. Но, думаю, вы согласитесь со мной, что не каждая работа по плечу любому 
человеку. Каждый из нас индивидуален. У кого-то в большей степени развиты одни способности, у кого-то другие. И для достижения наибольшей эффективности в работе появилось разделения труда. Общественное разделение труда касается не только людей, но и видов деятельности. Это относительное обособление видов деятельности, специализация работников на изготовление какого-либо продукта или совершение определенной трудовой операции [4].

С одной стороны разделение труда помогает людям эффективно взаимодействовать друг с другом. Повышается качество производимых товаров и предоставляемых услуг. Но, с другой стороны, из-за этой взаимосвязи практически невозможно работать одному. Появляются узкие специалисты, которые способны выполнять работу только в своей сфере [3].

Всего выделяют три формы общественного разделения труда: общая, частная, единичная. Рассмотрим каждую из них.

Общая форма разделения труда. Данная форма подразумевает выделение крупных видов деятельности человечества. Например, сельское хозяйство, промышленность и т.д.

Частная форма общественного разделения труда предполагает, в свою очередь, разделение крупных видов деятельности на подвиды. Так, в промышленности можно выделить металлургию, автомобилестроение; в сельском хозяйстве: пищевая промышленность, растениеводство и др.

Единичная форма общественного разделения труда - это дифференциация обязанностей внутри отдельного предприятия.

Стоит отметить, что каждая из форм общественного разделения труда неразрывно связана с другой. Так, общая форма разделения труда влияет на частную форму, что влечет за собой выделение новых отраслей в промышленности, сельском хозяйстве и др.

А c помощью частного разделения труда и образованию новых, специализированных отраслей, совершенствуется единичная форма разделения труда на предприятиях. 
Факторов, оказывающих влияние на разделение труда, очень много, но можно выделить самые главные:

- появление новых средств труда, сырья, энергии, обусловленных техническим прогрессом ;

- автоматизация производства, которая ведет к преобразованию состава отраслей;

- модернизация стандартов частных производств ведет к модификации орудий труда и разделения труда на предприятии;

Bсе приведенные выше факторы можно объединить в один, общий для всех них: фактор развития производительных сил. Именно он является главным для общественного разделения труда. Прогресс производительных сил человека лежал в основе появления разделения труда.

Развитие общественного разделения труда во многом повторило путь развития производительных сил. С появлением все новых технологий в производстве, промышленности, сельском хозяйстве требовалось все большее разделение труда. Современные отрасли промышленности не смогут эффективно функционировать без разделения обязанностей [1]. На каждом предприятии сегодня действуют множество отделов и цехов, у каждого из которых стоят свои, определенные задачи. Но, важно то, что они настолько взаимосвязаны, что не смогут работать по отдельности. Поэтому развитие производительных сил - фактор, влияющий на общественное разделение труда.

Делая вывод можно сказать, что производительные силы и разделение труда неразрывно связаны друг с другом. Именно поэтому при очередном скачке в развитии техники и науки появляются новые профессии и требуются все новые специалисты, как узких, так и широких специальностей. 


\section{Литература:}

1. Антропов В.А., Морозова Е.Н. Понятийно-терминологический аппарат формирования кадровой политики саморазвития промышленных и транспортных предприятий // Транспорт Урала.- 2015. -№ 1 (44). С. 1926.

2. Ленин, В. И. Полное собрание сочинений, издание пятое/ М.: Издательство политической литературы, 1973 (дата обращения 14.04.2016)

3. Морозова Е.Н., Антропов В.А. Управление интерспецифическими трудовыми ресурсами транспортных вузов. Екатеринбург: изд-во УрГУПС, 2014. -143 с.

4. Общественное разделение труда.

URL: http://abc.informbureau.com/html/iauanoaaiiia_dacaaeaiea_odoaa.html (дата обращения 14.04.2016)

5. Экономика и управление: мир необъятного. Монография для студентов технических и экономических специальностей, / Сост.: Долгов Д. И.2014. - 521 с. (дата обращения 14.04.2016) 